\title{
Dairy Factory Wastewater from Cumulative Point of View-A Case Study
}

\author{
Mehrfam Massah $^{1} \&$ Seyed Ahmad Mirbagheri ${ }^{2}$ \\ ${ }^{1}$ Department of Environment and Energy, Science and Research Branch, Islamic Azad University, Tehran, Iran \\ ${ }^{2}$ Khaje Nasir Toosi Head of the Environmental Engineering Board, Tehran, Iran \\ Correspondence: Mehrfam Massah, Department of Environment and Energy, Science and Research Branch, \\ Islamic Azad University, Tehran, Iran. E-mail: massah.mehrfam@gmail.com
}

Received: January 29, 2012 Accepted: February 9, 2012 Online Published: December 20, 2012

doi:10.5539/ep.v2n1p96

URL: http://dx.doi.org/10.5539/ep.v2n1p96

\begin{abstract}
It is needless to mention that, milk has the most appropriate and balanced combination among various foods that human feed on them daily and because of this fact milk is commonly called the perfect food. Therefore, milk and dairy products industries are one of the most important and necessary industries in all human societies. However, wastewater from this industry includes a variety of pollutants. The nature and combination of milk industry wastewater depends on the type of process being done on milk in factory and also type and combination of products that are produced in factory. In this study, the output effluent of a dairy factory was selected for investigation. Firstly, dairy wastewater specifications were introduced. Then, during 63 days, wastewater of plant was sampled ten times. Afterwards, temperature, nitrate, phosphate, BOD, COD, TSS, TDS, DO, $\mathrm{pH}, \mathrm{NH}_{4}$, salt were measured by special devices and methods. Afterwards, by correlation analysis the impressibility of each parameter than the other variables was evaluated. The amount of these factors was compared with existing standard. Then, the correlation coefficient of these factors was evaluated by using SPSS software.
\end{abstract}

Keywords: wastewater, dairy factory, pollution, Pearson correlation, Iran

\section{Introduction}

However expansion of human societies, industrial and technological development have brought special privileges, they cause several problems for societies (Hettige et al., 2000; Xepapadeas, 1997). The first result of human social and industrial activities was in the form of destruction of environment and contaminating water, soil, air resources and also all the factors which were effective for human having better life. Social and industrial developments were even intolerable for humans due to environment destruction and pollution (Leonard, 1982; Tsai \& Chou, 2004). Therefore, issues of environmental pollution were reviewed and discussed in various regional and global meetings in order to provide appropriate solutions for decreasing pollution (Böhm et al., 1998; Yhdego, 1995; Pravdić, 1995). Pollution threatens environment, sanitation and public health and it brings lots of difficulties for the intended use of resources. The environment pollution causes mortality of fish in rivers, contamination of underground water resources, water pollution in lakes and rivers, disappearance of suitable agricultural land and increase of diseases (Greenwood, 2008; Jadhav et al., 2011; Nicolai, 2002; Boyd \& Genuis, 2008). In many countries, special laws have been developed to combat this problem and specific standards have been legislated in order to avoid social disasters due to inattention of this fact (Arvanitoyannis et al., 2008; Bennett, 2009; Hessel et al., 2007; Soble \& Brennan, 1988). Although environmental laws have been developed in Iran, they are not applied in most cases. One of the most important environmental pollutants is industrial wastewater which is becoming more important day by day with the industrial rapid growth and economic development (Ntengwe, 2005; Lefebvre \& Moletta, 2006; Mohsen \& Jaber, 2003; Al-Muzaini, 1998; Libralato et al., 2012). There are currently several industries in our country which their wastewater have high pollution load including dairy industry wastewater that is considered as one of the most contaminated wastewater because of its special features. In Iran, dairy industry has an important role in providing dairy products and pasteurized milk. Milk contains water, fat, protein, lactose, minerals (salts) and various vitamins. The major minerals in milk are calcium, sodium, magnesium, potassium which these minerals are in the form of phosphate, chloride, nitrate, and casein. Also other elements such as sulfur, zinc, rubidium, silicon, boron, aluminum, iron are found in milk in small amounts. Dairy wastewater leads following phenomena when it is added to natural flowing water (Sarkar 
et al., 2006; Farizoglu \& Uzuner, 2011; Kushwaha et al., 2010; Banu et al., 2008; Belyea et al., 1990).

1) Dissolved oxygen in water is quickly consumed. Then, dissolved oxygen will be reduced.

2) The formation of sludge at the bottom of the river.

3) Growth of sewage fungus.

4) Gradual decrease in water $\mathrm{pH}$.

Biodegradation of organic compounds in wastewater consumes dissolved oxygen in water. As a result, it is added to the mass of sludge and it causes hydraulic problems in different parts of the region.

\section{Materials and Methods}

\subsection{Study Area}

Golpayegan is one of the cities of Isfahan. It is a city with an ancient culture. Its original name is Vart Padegan (Land of the Rose). It is located in the northwest of Isfahan and its distance from Isfahan is about $184 \mathrm{~km}$. Golpayegan geographic coordinates are $45^{\circ} 23^{\prime} \mathrm{N}, 28^{\circ} 50^{\prime} \mathrm{E}$. Its distance from the capital city of the province (Isfahan) is $190 \mathrm{~km}$ and its distance from Tehran is $352 \mathrm{~km}$. Golpayegan is restricted to Khomain city from north, Khansar city from south, Meymeh city from East and Aligudarz city from West. The area of Golpayegan is about $22421 \mathrm{~km}$ and the average height of the city is $1764 \mathrm{~m}$ above sea level. Golpayegan is located in relatively wide plain and it is surrounded with high mountains having fairly high peaks. It is worth noting that Golpayegan has a privileged position in milk production of the country due to its pastures and having animals with high milk quality.

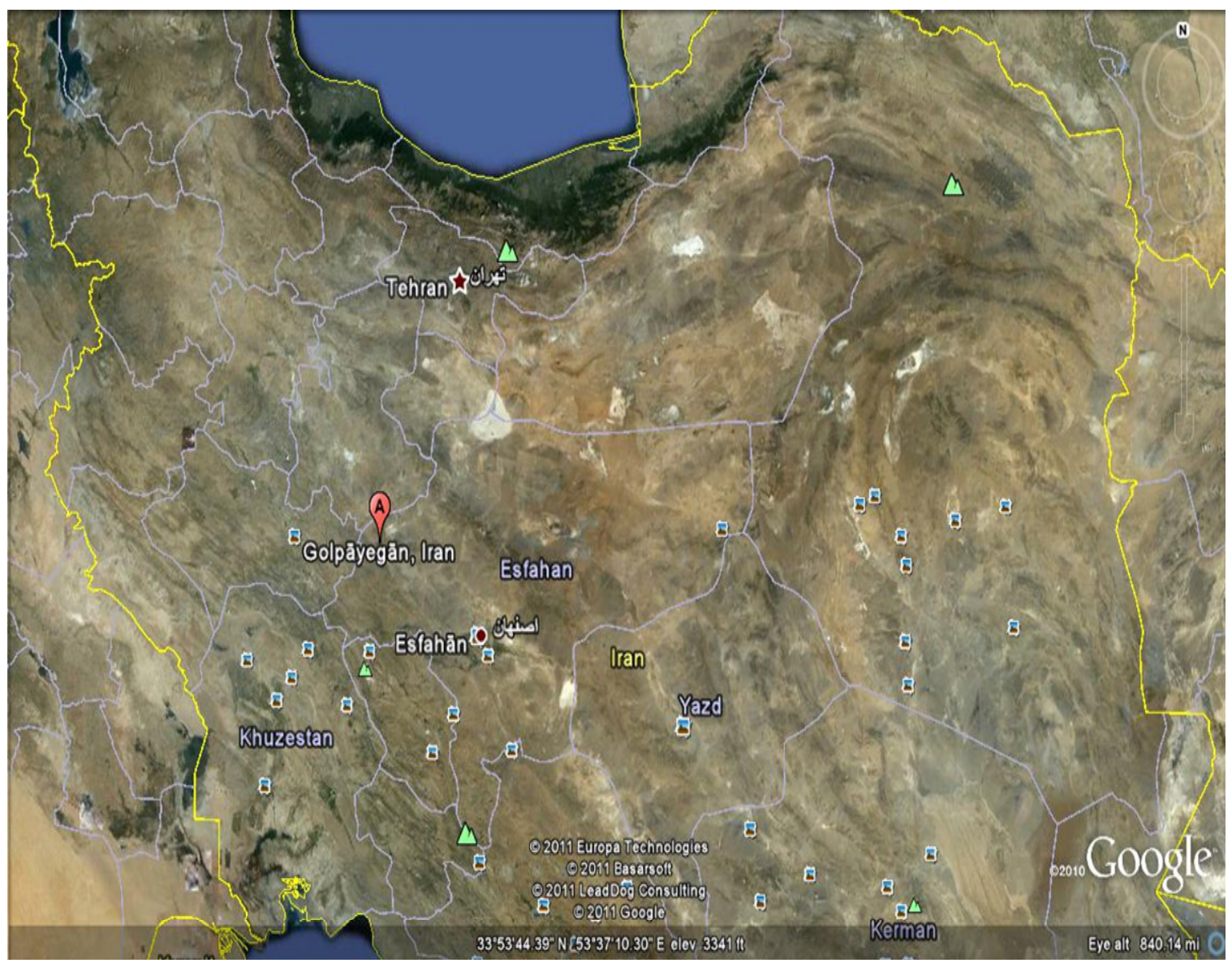

Figure 1. The situation of Golpaigan city in Iran 


\subsection{The Research Workflow}

In this study, all samples were measured without fixation on the grounds that the test site was close to the laboratory. Besides, sampling was done momentarily because the samples were from the output effluent of the plant. Sampling period was 63 days and the output of the effluent plant was sampled 10 times during this period of time. In this study, the examined parameters were electrical conductivity (EC), biological Oxygen Demand (BOD5), chemical Oxygen demand (COD), dissolved oxygen (DO), $\mathrm{pH}$, total suspended solids (TSS), ammonia, nitrogen, phosphate and nitrate. It should be mentioned that EC meters (EC Terminal Level 3 manufactured INOLAB) was used in order to measure parameters such as COD, TDS and Salt.

For measurements of COD with using EC meter (model: EC Terminal level manufactured by Inolab Co.) spectrophotometer, firstly $2 \mathrm{CC}$ of the output of effluent or $0.2 \mathrm{CC}$ of the raw sewage threw respectively within solutions of 0-1500 and 0-15000 Vials. Then, it was mixed several times. The control sample was prepared by throwing $2 \mathrm{CC}$ distilled water for $0-1500$ and $0.2 \mathrm{CC}$ for $0-15000$ into the relevant vials. The obtained mixture was put in heater or furnace. (COD Reactor $150{ }^{\circ} \mathrm{C} \mathrm{HACH}$ manufactured by America) for 2 hours to be digested. The digested samples were brought out of the heater in order to have the same temperature as the room temperature. In this case, bottles containing examined mixtures were cleaned with tissue and they were put inside the device (Spectro Photometer Dr/2000 in manufactured by HACH in America) and the amount of COD was recorded. The standard solution of potassium biphthalate was used to ensure the Accuracy of results obtained. Besides, device (Dissolved oxygen 55 Handheld Construction Company YSI incorporated in America) was used to measure DO. For measurement of $\mathrm{BOD}_{5}$, samples were heated up to $20^{\circ} \mathrm{C}$ and the amount of needed sample based on the estimated $\mathrm{BOD}_{5}$ was put in glass bottles of the device (6-channel BOD Trak TM manufactured by $\mathrm{HACH}$ company in America) by using a graded container. For raw sewage, $20 \mathrm{CC}$ of the sample with $80 \mathrm{CC}$ of effluent samples were diluted. Then $95 \mathrm{CC}$ of the sample was put aside. For effluent samples $420 \mathrm{CC}$ (for the range of 0-35) and $355 \mathrm{CC}$ (for the range of 0-70) were taken before chlorination and they were thrown into bottles. A piece of magnetic device was set inside the bottle and a package of nutrients was added to sample if it was necessary. (This is not usually needed considering that the samples related to the dairy companies are rich in terms of nutrients). The rubber cap of the bottle was lubricated by special grease and a package of lithium hydroxide was put into the cap. If lithium hydroxide was accidentally collapsed, samples had to be replaced).The glass bottle was put inside BOD meter machine and formerly incubator. Then, the device was turn on. It had to be checked that the rotational motion of magnetic Device Inside glass bottle work correctly. Then, the $\mathrm{BOD}_{5}$ levels were determined. The device (pH-Meter 766 Calimatic Manufactured by Kniclc Company) was used in order to determine the sample $\mathrm{pH}$. Total suspended solid was measured by the following formula:

$$
\text { Total suspended solids per liter } m g=1000 \times(A-B-C) / \text { Sample size Liter }
$$

A: weight of filter and Solids (gr)

B: filter weight (gr)

C: correction control $(\mathrm{gr})=$ (final weight of control filter) - (initial weight of control filter)

Measurement of ammonia nitrogen was done by spectrophotometer device.

For the measurement of phosphate, $10 \mathrm{ml}$ of sample was taken and this volume had to be increased to the volume of $50 \mathrm{ml}$. Then, $0 / 5 \mathrm{ml}$ of sulfuric acid and $5 \mathrm{ml}$ ammonium Molybdat, $2 \mathrm{Ml}$ amino Naftol sulfonic acid were respectively added. After each step, the sample had to be mixed properly. Then, the sample had to be kept for five minutes in still position. Next, phosphate absorption was measured in the vicinity of distilled water as control by spectrophotometer on the wavelength of $650 \mathrm{~nm}$ and the amount of phosphate was determined from the standard curve. It is notable that distilled water and applied reagents are better to be used as control in spectrophotometric methods. For the measurement of nitrate, $20 \mathrm{ml}$ of sample was filtered and put in a suitable container. Then, 1 or $2 \mathrm{ml}$ sodium salicylate solution was added to the container and it was put on the hot tubs to be dried out by steam. (The volumes of taken samples were dependent on nitrate concentrations, it is possible to take small amount and dilute it with distilled water). Then, the sample was put inside a dryer at $150{ }^{\circ} \mathrm{C}$ for 2 hours. Afterwards, it was put in a desiccator to decrease the temperature and $2 \mathrm{Ml}$ of sulfuric acid was added to the sample (The change of color means that the measurement method is appropriate). After ten minutes, $15 \mathrm{ml}$ of distilled water and $15 \mathrm{ml}$ of sodium tartrate solution Potassium tartrate-Sodium hydroxide was added and after ten minutes solution absorption was measured on $420 \mathrm{~nm}$ wavelength. Standard curve which was prepared in the same way was used to determine Nitrate concentrations. The control was prepared using $20 \mathrm{ml}$ of distilled water and the following reagents and without nitrate. After determining the above parameters Using SPSS software, the 
collected data was analyzed.

\section{Discussion}

Pearson correlation values was calculated for determining the amount of linear relationship and the meaningful test of this amount was done in terms of statistical analysis at Significant level of 0.05 considering that data were continuous and also Kolmogorov-Smirnov Non-parametric test confirmed the assumption that all variables were normal in significant level of 0.05 (Last row in the table below). (If p-value $<0.05$, the zero assumption at meaningful level of 0.05 is rejected. As a result the test is meaningful in terms of statistical analysis. Indeed, relationship between two variables is approved.)

Table 1. One-sample Kolmogorov-smirnov test

\begin{tabular}{|c|c|c|c|c|c|c|c|c|c|c|c|}
\hline & $\mathrm{Tem}{ }^{\circ} \mathrm{C}$ & $\begin{array}{l}\text { BOD } \\
\mathrm{mg} / 1\end{array}$ & $\begin{array}{l}\mathrm{COD} \\
\mathrm{mg} / 1\end{array}$ & $\mathrm{PH}$ & $\begin{array}{l}\text { SALT } \\
\mathrm{mg} / 1\end{array}$ & $\begin{array}{l}\mathrm{DO} \\
\mathrm{mg} / 1\end{array}$ & $\begin{array}{l}\mathrm{TSS} \\
\mathrm{mg} / \mathrm{l}\end{array}$ & $\begin{array}{l}\text { TDS } \\
\mathrm{mg} / 1\end{array}$ & $\begin{array}{l}\mathrm{NH}_{4} \\
\mathrm{mg} / 1\end{array}$ & $\begin{array}{l}\mathrm{NO}_{3} \\
\mathrm{mg} / 1\end{array}$ & $\mathrm{PO}_{4} \mathrm{mg} / \mathrm{l}$ \\
\hline $\mathrm{N}$ & 10 & 10 & 10 & 10 & 10 & 10 & 10 & 10 & 10 & 10 & 10 \\
\hline $\begin{array}{c}\text { Normal } \\
\text { Parameters } \\
\text { Mean }\end{array}$ & 8.5000 & 26.5000 & 52.1000 & 7.7500 & 00.518 & 2.7100 & 74.4000 & 285.9000 & 3.8260 & 23.7000 & 100.9200 \\
\hline Std.Deviation & 4.40328 & 6.81909 & 7.48999 & 0.07071 & 0.00253 & 0.48637 & 5.25357 & 91.27171 & 0.54700 & 1.16905 & 1.91358 \\
\hline $\begin{array}{c}\text { Most Extreme } \\
\text { Absolute }\end{array}$ & 0.145 & 0.271 & 0.156 & 0.360 & 0.268 & 0.224 & 0.148 & 0.191 & 0.254 & 0.132 & 0.124 \\
\hline $\begin{array}{c}\text { Differences } \\
\text { Positive }\end{array}$ & 0.145 & 0.271 & 0.156 & 0.360 & 0.268 & 0.113 & 0.148 & 0.191 & 0.214 & 0.104 & 0.097 \\
\hline Negative & -0.085 & -0.170 & -0.100 & -0.240 & -0.238 & -0.224 & -0.145 & -0.152 & -0.254 & -0.132 & -0.124 \\
\hline $\begin{array}{c}\text { Kolmogorov } \\
\text {-Smirnov Z }\end{array}$ & 0.459 & 0.856 & 0.495 & 1.139 & 0.849 & 0.710 & 0.468 & 0.604 & 0.803 & 0.418 & 0.392 \\
\hline $\begin{array}{c}\text { Asymp.Sig. } \\
\text { (2-tailed) }\end{array}$ & 0.984 & 0.456 & 0.967 & 0.149 & 0.467 & 0.695 & 0.981 & 0.859 & 0.540 & 0.995 & 0.998 \\
\hline
\end{tabular}

a. Test distribution is normal

b. Calculated from data

Results of the research showed that Pearson correlation between BOD and Temperature was a strong positive correlation (Figure 2). 


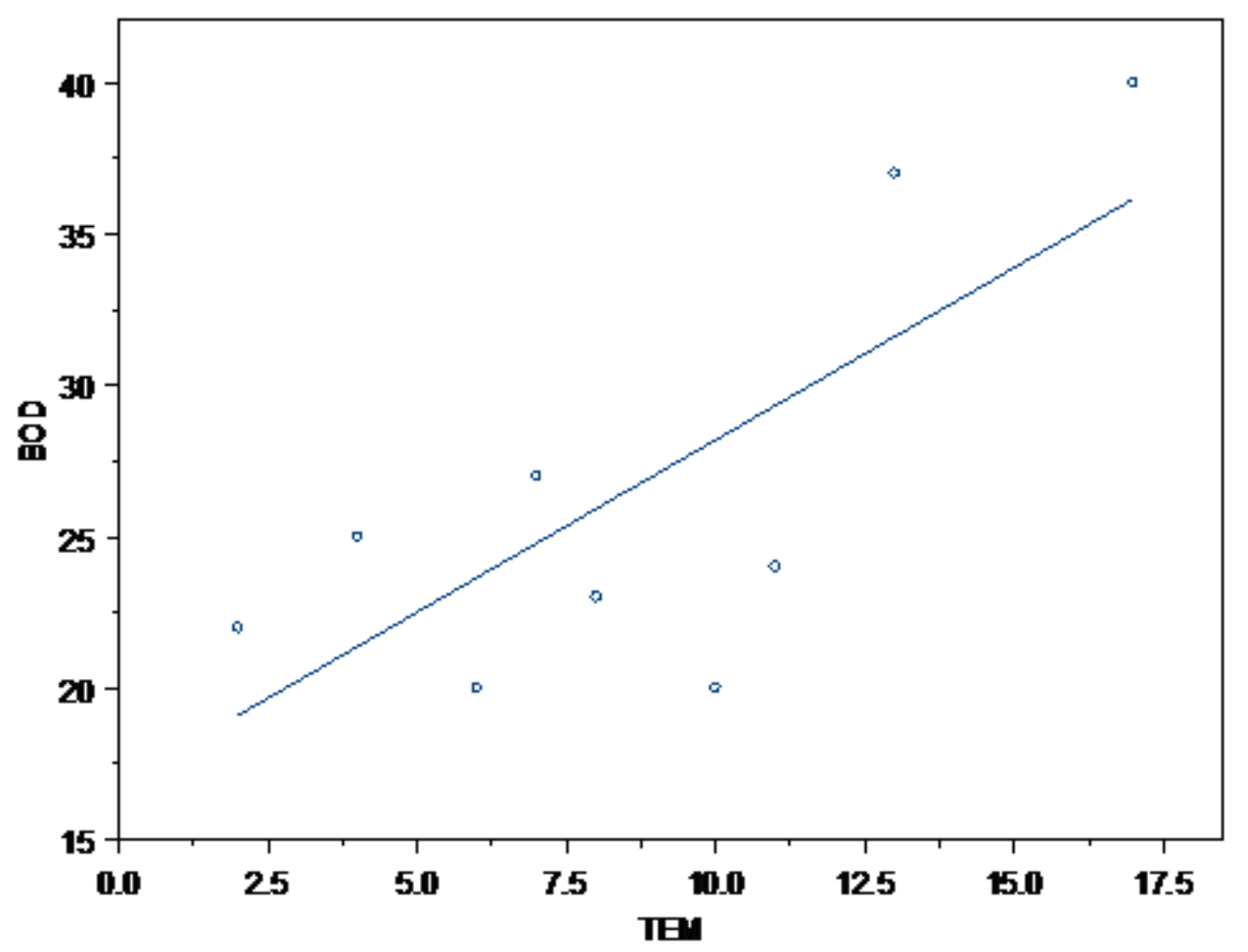

Figure 2. Correlation between BOD and TEM

The correlation was meaningful in terms of statistical analysis according to the $p$-value $=0.016$. The correlation between temperature and COD indicated a relatively weak linear correlation and in the positive direction (when one increased the other one increased too and Vice versa). Besides, it was not statistically significant. The value of Pearson correlation between DO and temperature was -0.646 which revealed a negative strong linear correlation (when one increased the other one decreased and vice versa). This correlation, in terms of statistical analysis, was meaningful at the level of 0.05 according to $p$-value $=0.044$. The value of Pearson correlation between $\mathrm{NH}_{4}$ and temperature was 0.546 representing a linear correlation that was rejected statistically. The value of Pearson correlation between $\mathrm{NO}_{3}$ and temperature was 0.427 which depicted a positive weak linear correlation. This correlation, in terms of statistical analysis, was not meaningful at the level of 0.05 according to $\mathrm{p}$-value $=0.218 . \mathrm{BOD}_{5}$ and $\mathrm{COD}$ had positive and relatively strong linear correlation. This correlation, in terms of statistical analysis, was meaningful at the level of 0.05 according to p-value $=0.04 . \mathrm{BOD}_{5}$ and $\mathrm{NH}_{4}$ had a positive strong linear correlation. This correlation, in terms of statistical analysis, was meaningful at the level of 0.05 according to $\mathrm{p}$-value $=0.007$. The value of Pearson correlation between $\mathrm{DO}$ and $\mathrm{BOD}_{5}$ was -0.551 which revealed a positive strong linear correlation. This correlation, in terms of statistical analysis, was not meaningful at the level of 0.05 according to $\mathrm{p}$-value $=0.099 . \mathrm{BOD}_{5}$ and $\mathrm{NH}_{4}$ had a positive and relatively weak linear correlation. This correlation, in terms of statistical analysis, was not meaningful at the level of 0.05 according to p-value $=0.05 . \mathrm{COD}$ and $\mathrm{NO}_{3}$ had a relative positive linear correlation. This correlation, in terms of statistical analysis, was not meaningful at the level of 0.05 according to p-value $=0.085$. COD and $\mathrm{PO}_{4}$ had a relative positive linear correlation. This correlation, in terms of statistical analysis, was not meaningful at the level of 0.05 according to $\mathrm{p}$-value $=0.149$. $\mathrm{COD}$ and $\mathrm{NH}_{4}$ had a relative positive linear correlation. This correlation, in terms of statistical analysis, was not meaningful at the level of 0.05 according to $\mathrm{p}$-value $=0.286$. COD and $\mathrm{pH}$ had a relative positive linear correlation. This correlation, in terms of statistical analysis, was not meaningful at the level of 0.05 according to $\mathrm{p}$-value $=0.327$. The value of Pearson correlation between $\mathrm{DO}$ and $\mathrm{PO}_{4}$ was -0.58 which revealed a relative negative linear correlation. This correlation, in terms of statistical analysis, was not meaningful at the level of 0.05 according to $p$-value $=0.079$. The value of Pearson correlation between DO and $\mathrm{NO}_{3}$ was -0.227 which revealed a very weak and negative linear correlation. This correlation, in terms of statistical analysis, was not meaningful at the level of 0.05 according to $p$-value $=0.529$. The value of Pearson correlation between DO and COD was -0.202 which revealed a very weak and negative linear correlation. This 
correlation, in terms of statistical analysis, was not meaningful at the level of 0.05 according to $p$-value $=0.576$.

\section{Conclusion}

The obtained results suggested that by increasing the temperature, the Dissolved Oxygen (DO) is decreased while the $\mathrm{BOD}_{5}$ level is increased. Increased temperature provides a suitable environment for the growth of bacteria and microorganisms. Then, more amount of oxygen is consumed in decomposition systems. The $\mathrm{pH}$ level is an effective factor in accelerating deposition process. Increased $\mathrm{pH}$ level rises sedimentation rate. The $\mathrm{pH}$ level is raised when temperature is increased and the water has alkali nature. As a result, $\mathrm{PO}_{4}$ concentration is also increased. The obtained results showed that all the factors analyzed in this study are within the standard ranges of agricultural effluent. In addition, in the plant, some of the pollutant factors such as Coli form are not investigated due to lack of microbiological and biological laboratory It is noteworthy that the plant does not have. high amount of Alkali and acid are consumed for washing machines and plant. This causes more pollution in plant effluent. Rising alkali and acid rates in plant is one of the reasons of EC increase and fluctuation of $\mathrm{pH}$ in the waste. Factors such as lack of planning in production, lack of expertise, lack of digital devices for accurate measurement of alkali and acid, the use of manual and traditional methods increase acid and alkali consumption in the plant. As a useful tool, a central and digital CIP has been established in Pegah Factory in Zanjan to reduce acid and alkali consumption In addition, in Pegah Factory instead of UASB Reactor, UABR Reactor has been used and the result is more desirable. Besides, sudden changes in the volume of wastewater occurred as a result of sudden changes in the type and volume of the production cause problems in operation of UASB Reactor. The output effluent of Pegah Factory in Golpayegan cannot be used for irrigation of seedlings, fruit trees and farm fields because of high amount of emissions such as EC. The only usage of plant effluent is irrigation of green spaces especially pine trees in the factory. Pegah Factory in Golpayegan is generated 350 cubic meters of wastewater per day. It is noteworthy that the amount of produced wastewater, the composition of the plant wastewater depending on the type and volume of the products varys in different seasons of the year.

\section{Acknowledgments}

The research ahead has been extracted of a MSc Thesis at Islamic Azad University, Science and Research Branch of Tehran. The authors hereby would like to express their gratitude to the university authorities for their sincere cooperation.

\section{References}

Al-Muzaini, S. (1998). Industrial wastewater management in Kuwait. Desalination, 115(1), 57-62.

Arvanitoyannis, I. S., Tserkezou, P., \& Choreftaki, S. (2006). An update of US food safety, food technology, GM food and water protection and management legislation. International Journal of Food Science and Technology, 41, 130-159. http://dx.doi.org/10.1111/j.1365-2621.2006.01266.x

Banu, R. J., Anandan, S., Kaliappan, S., \& Yeom, I. T. (2008). Treatment of dairy wastewater using anaerobic $\begin{array}{lllll}\text { and solar photocatalytic methods. Solar Energy, } & \text { 82(9), }\end{array}$ http://dx.doi.org/10.1016/j.solener.2008.02.015

Belyea, R. L., Williams, J. E., Gieseke, L., Clevenger, T. E., Brown, J. R., \& Tumbleson, M. E. (1990). Evaluation of Dairy Wastewater Solids as a Feed Ingredient. Journal of Dairy Science, 73(7), 1864-1871. http://dx.doi.org/10.3168/jds.S0022-0302(90)78867-4

Bennett, A. (2009). Legislation and market forces: Regulators and wastewater reuse. Filtration \& Separation, 46(5), 16-18; 20-21. http://dx.doi.org/10.1016/S0015-1882(09)70189-2

Böhm, P., Wolterbeek, H., Verburg, T., \& Musilek, L. (1998). The use of tree bark for environmental pollution monitoring in the Czech Republic. Environmental Pollution, 102(2-3), 243-250. http://dx.doi.org/10.1016/S0269-7491(98)00082-7

Boyd, D. R., \& Genuis, S. J. (2008). The environmental burden of disease in Canada: Respiratory disease, cardiovascular disease, cancer, and congenital affliction. Environmental Research, 106(2), 240-249. $\mathrm{http}: / / \mathrm{dx}$.doi.org/10.1016/j.envres.2007.08.009

Farizoglu, B., \& Uzuner, S. (2011). The investigation of dairy industry wastewater treatment in a biological high performance membrane system. Biochemical Engineering Journal, 57, 46-54. http://dx.doi.org/10.1016/j.bej.2011.08.007

Greenwood, M. F. D. (2008). Fish mortality by impingement on the cooling-water intake screens of Britain's largest direct-cooled power station. Marine Pollution Bulletin, 56(4), 723-739. http://dx.doi.org/10.1016/j.marpolbul.2007.12.008 
Hessel, C., Allegre, C., Maisseu, M., Charbit, F., \& Moulin, P. (2007). Guidelines and legislation for dye house effluents. Journal of Environmental Management, $83(2), \quad$ 171-180. http://dx.doi.org/10.1016/j.jenvman.2006.02.012

Hettige, H., Mani, M., \& Wheeler, D. (2000). Industrial pollution in economic development: the environmental Kuznets curve revisited. Journal of Development Economics, 62(2), 445-476. http://dx.doi.org/10.1016/S0304-3878(00)00092-4

Jadhav, S., Bhosale, D., \& Bhosle, N. (2011). Baseline of organotin pollution in fishes, clams, shrimps, squids and crabs collected from the west coast of India. Marine Pollution Bulletin, 62(10), 2213-2219. http://dx.doi.org/10.1016/j.marpolbul.2011.06.023

Kushwaha, P. J., Srivastava, C. V., \& Mall, I. D. (2010). Treatment of dairy wastewater by inorganic coagulants: Parametric and disposal studies. Water Research, 44(20), 5867-5874. http://dx.doi.org/10.1016/j.watres.2010.07.001

Lefebvre, O., \& Moletta, R. (2006). Treatment of organic pollution in industrial saline wastewater: A literature review. Water Research, 40(20), 3671-3682. http://dx.doi.org/10.1016/j.watres.2006.08.027

Leonard, H. J. (1982). Environmental regulations, multinational corporations and industrial development in the 1980s. Habitat International, 6(3), 323-341. http://dx.doi.org/10.1016/0197-3975(82)90007-8

Libralato, G., Ghirardini, A. V., \& Avezzù, F. (2012). To centralise or to decentralise: An overview of the most recent trends in wastewater treatment management. Journal of Environmental Management, 94(1), 61-68. http://dx.doi.org/10.1016/j.jenvman.2011.07.010

Mohsen, M. S., \& Jaber, J. O. (2003). Potential of industrial wastewater reuse. Desalination, 152(1-3), 281-289. http://dx.doi.org/10.1016/S0011-9164(02)01075-5

Nicolai, T. (2002). Pollution, environmental factors and childhood respiratory allergic disease. Toxicology, 181-182, 317-321. http://dx.doi.org/10.1016/S0300-483X(02)00300-1

Ntengwe, F. W. (2005). An overview of industrial wastewater treatment and analysis as means of preventing pollution of surface and underground water bodies-the case of Nkana Mine in Zambia. Physics and Chemistry of the Earth, Parts A/B/C, 30(11-16), 726-734. http://dx.doi.org/10.1016/j.pce.2005.08.014

Pravdić, V. (1995). The chemical industry in the Croatian Adriatic region: identification of environmental problems, assessment of pollution risks, and the new policies of sustainability. Science of the Total Environment, 171(1-3), 265-274. http://dx.doi.org/10.1016/0048-9697(95)04694-8

Sarkar, B., Chakrabarti, P. P., Vijaykumar, A., \& Kale, V. (2006). Wastewater treatment in dairy $\begin{array}{lllll}\text { industries-possibility of } & \text { reuse. }\end{array}$ http://dx.doi.org/10.1016/j.desal.2005.11.015

Soble, S. M., \& Brennan, J. H. (1988). A review of legal and policy issues in legislating compensation for victims of toxic substance pollution. Social Science \& Medicine, 27(10), 1061-1070. http://dx.doi.org/10.1016/0277-9536(88)90301-2

Tsai, W. T., \& Chou, Y. H. (2004). Government policies for encouraging industrial waste reuse and pollution prevention in Taiwan. Journal of Cleaner Production, 12(7), 725-736. http://dx.doi.org/10.1016/S0959-6526(03)00053-2

Xepapadeas, A. (1997). Economic development and environmental pollution: traps and growth. Structural Change and Economic Dynamics, 8(3), 327-350. http://dx.doi.org/10.1016/S0954-349X(96)00072-0

Yhdego, M. (1995). Environmental pollution management for Tanzania: towards pollution prevention. Journal of Cleaner Production, 3(3), 143-151. http://dx.doi.org/10.1016/0959-6526(95)00001-U 